\title{
Kazakh Multi Vector Foreign Policy in Action
}

\section{Kaan Diyarbakırlığlu ${ }^{1}$, Süreyya Yiğit ${ }^{2}$,}

\begin{abstract}
The post-Cold War has ushered in many changes. One of which is the re-emergence of regions that were once considered at the periphery of international relations. A good example of this is central Asia. Throughout the Cold War central Asia was an area much maligned in terms of research within the academic field. The re-emergence of the Turkic Republics in this particular geographic region has attracted the attention of policymakers in the western world. The primary country that has gained the greatest importance has been Kazakhstan. Kazakhstan has faced a difficult dilemma: maintaining good relations with two extremely powerful neighbours, namely, the Russian Federation and China. This article aims to shed light on the Multi-vector foreign policy identified by Kazakhstan to not only maintain its stability and existence within a volatile region, but to emerge as the most powerful country in central Asia. The various challenges and opportunities that have been presented to Kazakhstan are analysed and explanations provided for the actions that have been taken in the post-Cold War era. Ultimately this article presents a codification of the concept of a multi-vector foreign policy in action over the past two decades.
\end{abstract}

Keywords: Kazakhstan, foreign policy, central Asia, energy, Nazarbayev

\footnotetext{
${ }^{1}$ Yalova Üniversitesi

2 İstanbul Aydın Üniversitesi
} 


\section{Introduction}

The world is divided into seven continents. They are classified as Asia, Africa, Antarctica, Europe, North America, South America and Australia. Of these the most populated is Asia, which is also the largest in terms of size, covering more than 44 million $\mathrm{km} 2$. In the beginning of the $20^{\text {th }}$ century Asia was heralded as the most important continent in terms of geopolitics by Mackinder. In his famous study in 1904 entitled "The Geographical Pivot of History"1 he identified an area which he termed the "WorldIsland' which comprised the interlinked continents of Europe, Asia, and Africa. At the time this was the largest, most populous, and richest of all possible land combinations. Within this the most important land mass was the 'Pivot Area' or the 'Heartland' which began on the banks of the Volga and stretched to the Yangtze, covering the area from the Himalayas to the Arctic. Mackinder developed this further in 1919 by famously declaring that "Who rules East Europe commands the Heartland; who rules the Heartland commands the World-Island; who rules the World-Island controls the world." The reasoning behind was simple: whichever power controlled the World-Island would control more than half the world's resources. It was the size and central position of the Heartland which made it the key to controlling the World-Island.

At the time the single power that controlled the 'pivot area' was the Russian Empire. In 1917 this was taken over by the Bolshevik revolutionaries which established the Soviet Union. In 1991 with the collapse of the Soviet Union this area became divided among many newly independent states for the first time since the expansion of the Russian Empire. A century after, Mackinder's famous assertion remains relevant, still holding some truth. The qualification is that the pivot area - bereft of access to the world's oceans - does not offer total global domination. Even if the areas were to be controlled by a single power, it is highly unlikely that it would be a unipolar power.

A century ago the pivot area possessed vast amounts of natural resources, which were hardly considered vital. Today, the Caucasus, Central Asia and the Russian Far East as well as the territory beyond the Urals continues to attract much international attention due to the fact that it is an oil and gas powerhouse. Energy poor states surrounding the region look with ever hungry eyes towards importing oil and gas. Within the pivot area greater attention is currently being placed on Central Asia. Most of the Turkic states that form this region have been blessed with huge quantities of hydrocarbon resources.

Within Central Asia the most noteworthy Turkic state with regard to both hydrocarbon resources as well as territorial size is Kazakhstan. It is this country which has attracted the attention of energy import dependent neighbours as well as global energy companies located in different continents. It is difficult to assert that Mackinder's proposition is the main driving force for these countries and companies. Countries such as China and companies such as Chevron are purely and simply focused on the oil and gas that lie beneath Kazakh territory. They are interested in Nigeria for the same reason. This provides additional evidence that for many interested parties it is not the "Heartland" concept that explains their motives. Nevertheless, the location of Kazakhstan is an important factor to bear in mind when evaluating the significance of Astana in regional and global relations.

\section{Foreign Policy}

In terms of foreign policy for all states such a policy begins at their borders. Priority is always given to neighbouring states as they have historically been targeted and classified as potential invaders. A vast majority of states in existence today have experienced conflict with neighbouring powers in the past. Such knowledge of history has elevated relations with neighbours to the very top of the foreign policy agenda for practically nearly all countries of the world. There are quite naturally current and historic exceptions to this rule. It is difficult to argue that Washington's primary foreign policy goal today is to maintain good relations with Ottawa and Mexico City. Equally, one could not make the case during the cold war that the most pressing foreign policy aim of the Soviet Union was to protect itself from 
neighbouring states. Nevertheless, for most countries foreign policy begins on their shorelines and land borders.

This is certainly the case with Kazakhstan as it shares land borders with five states: China 1,765 km, Kyrgyzstan 1,212 km, Russia 7,644 km, Turkmenistan $413 \mathrm{~km}$ and Uzbekistan 2,330 km. ${ }^{2}$ Apart from these countries there are important regional states such as Turkey - sharing vital characteristics such as common ancestry, ethnicity, culture and religion - Iran and India that also appear prominently on the foreign policy milieu, though it is the United States which is undoubtedly the most important extra-regional power that captures much of the time and effort of Kazakh diplomats and decisionmakers.

Making foreign policy is an arduous task not only due to an unpredictable external environment but also due to a myriad of internal influences, demands, desires and interests. In the Kazakh context Ipek $^{3}$ argues that one must take into account the impact of "the nature of the regime in its post-Soviet state-building process; questions of national identity; the influence of domestic groups, especially clans, on government policy; Kazakhstan's landlocked geography; the interests of neighbouring powers; and the investment of multinational corporations (MNCs) in the rich oil and gas."

Principally due to its resources and location, Kazakhstan quickly found itself at the time of independence facing a triangular foreign policy. The Kazakhs primarily had to deal with Moscow, Beijing and Washington before contemplating other capitals when formulating its independent foreign policy. Kazakhs faced a very different world in 1991 as an independent entity when compared to their only other independent experience of Alash Orda. ${ }^{5}$ China the large neighbour to the east remained but gone was the Soviet Union - out of which Kazakhstan emerged - to be replaced with the Russian Federation. This fragmentation also created new Turkic neighbours to the south and west.

In such an environment Kazakhstan faced a nuclear ex-superpower to its west and a nuclear emerging superpower with more than a billion people to its east. The best approach to take at that time, under such circumstances came to be termed a "multi vector" foreign policy. ${ }^{6}$ Sultanov underlines this point by stating that "since obtaining independence Kazakhstan's foreign policy has been based on a principle of multi-vector relations that was declared by....Nazarbayev as soon as he was elected the country's president on 1 December 1991."7

The essential features of such a policy accepted the reality of two major powers neighbouring Kazakhstan and the necessity of maintaining good bilateral relations with each geopolitical actor. Ultimately, Astana's relations with Beijing could not be at the expense of its relations with Moscow and vice versa. Shaikhutdinov asserts that "from the first days of its independence Kazakhstan has pursued a balanced, pragmatic and responsible foreign policy, the main goal of which is to create a favorable international environment for the implementation of priority tasks in the economic and political modernization of Kazakhstan."

Nazarbayev considered the policy as "the development of friendly and predictable relations with all states that play a significant role in global politics and represent practical interest for our country. Kazakhstan....cannot limit itself to narrow-regional problems. This would not be understandable to not only our multiethnic population but the entire international community. Kazakhstan's future is both in Asia and Europe,in East and West."'

Ipek has noted the energy dimension of the policy by arguing "that Kazakhstan has been following a multi-vector foreign policy in strict relation to oil and gas contracts, given the determining influence of geopolitics and the pragmatism of the Kazakh leadership in its foreign policy discourse."10 Nazarbayev has explained the relevance of the multi vector foreign policy in another dimension, particularly in terms of defense by emphasising that it "will be able avert any manifestations of threats to Kazakhstan's security." 11

As an independent state Kazakhstan desired to keep all options open in the realm of international relations and the multi vector approach enabled the Kazakhs to maintain newly gained independence and engage in autonomous action. Blank locates this in the context of how the Kazakh President evaluates the region: "Nazarbayev clearly feels that Russia, China, and the United States each wish to dominate Central Asia, and he is determined to preserve his administration's autonomy in the 
face of this and other threats". ${ }^{12}$ Shaikhutdinov believed there was no alternative to such a policy by remarking that "being in the heart of Eurasia, at the intersection of different worlds and civilizations, Kazakhstan must therefore necessarily develop a multi-vector strategy aimed at collaboration and cooperation with other countries, integration projects and military-political blocs. This is especially important now, when Kazakhstan and Central Asia as a whole are facing serious challenges and threats." 13

Therefore, the multi vector foreign policy approach has been the defining feature of Kazakhstan in its foreign relations. As recently as September 2013 Nazarbayev reiterated that a "multi-vector foreign policy means the development of predictable and friendly relationships with all countries. Kazakhstan, due to its regional and economic potential, should not be concerned only about national issues. Through multi-vector policy, we can eliminate any manifestation of threats to the security of Kazakhstan."14

Furthermore, this issue was once again addressed by the new foreign policy concept adopted in 2014 stating that "Kazakhstan's foreign policy is based on the principles of multi-vector, balance, pragmatism, mutual benefit, and solid defense of its national interests." 15

\section{Russia}

Russia is a vital partner for Kazakhstan for a variety of reasons that primarily include economic, political, ethnic, linguistic, demographic, religious and geographical factors. The two countries are closely linked thorough a common border - the world's longest land border - playing a notable role. In fact, of Russia's 27 regions bordering CIS countries, twelve border Kazakhstan's 7 regions along the 7,591-km-long border. This demands efficient counteraction to real threats and challenges around Kazakhstan, which can be seen as a far outpost for both the Russians and the EU.

Following this theme, it is the human dimension which is another important one to bear in mind with estimates of over a million ethnic Kazakhs living in Russia as well as more than 4 million ethnic Russians living as citizens of Kazakhstan being of particular significance to the development of good bilateral relations. The two countries have been interested and active throughout the past two decades in political, trade and economic, cultural and humanitarian and military and technical cooperation.

Diplomatic relations between Kazakhstan and the Russian Federation began on October 22, 1992. ${ }^{16}$ So far more than 300 treaties and agreements have been signed.

The foundation of this relationship is centered on the following bilateral agreements: ${ }^{17}$

- Treaty on Friendship, Co-operation and Mutual Assistance of May 25, 1992;

- Declaration on Eternal Friendship and Alliance aimed for the XXI century of July 6, 1998.

- Protocol on Amendments to the Treaty on Friendship, Co-operation and Mutual Assistance of May 25, 1992. (This was signed on July 7, 2012 and ratified by both parties in June 2013.)

The characteristic of bilateral relations involves intensive political contacts, primarily it has been summit contacts between the two countries which have been actively sustained.

2012 proved to be a year in which high level political consultation, primarily in the form of summit contacts between the two countries took place. 15 summits as well as other high-level meetings took place in that year - 9 presidential summits, and 6 meetings at the prime-ministerial level. ${ }^{18}$ 
Furthermore, in 2012, five meetings of the Chairmen of Chambers of Parliaments of Russia and Kazakhstan were held. Parliamentary contacts between the two countries have also been actively pursued since. ${ }^{19}$ One must also note that co-operation between Russia and Kazakhstan also takes place within the confines of the CIS and other integration initiatives such as the CSTO, EurAsES, SCO and CICMA.

\section{Economic Relations}

Bilateral economic relations were put on a new footing by the Economic Co-operation Program for 2012-2020 which was signed on November 25, 2011 in Astana. ${ }^{20}$ A year later on December 19, 2012 in Moscow, the Joint Operating Plan for Russia and Kazakhstan for the Years 2012-2015, a strategic document, determining key tasks of bilateral co-operation was signed by the two Heads of State. ${ }^{21}$

When looking at the level of trade between the two countries the Russian Federal Customs Service has stated that the volume of mutual trade for 2012 increased by $8.5 \%$ compared to the previous year reaching 22.4 billion USD. ${ }^{22}$ Russian supplies increased by more than 3\% (up to 14.6 billion USD), whereas imports from Kazakhstan grew by nearly $20 \%$ (up to 7.9 billion USD).

The trend in increasing trading relations continued in the first half of 2013 as during the period January-July 2013 the volume of mutual trade increased significantly, by $18.8 \%$ reaching crossing the threshold of 13 billion USD, as compared to the corresponding period of 2012. Russian supplies increased by $12.6 \%$ (up to 7.9 billion USD), whereas imports from Kazakhstan increased by almost $30 \%$ (up to 5.2 billion USD). ${ }^{23}$

The Russian Federal Customs Service statistics for 2012/January-July2013, show that Kazakhstan's export structure to Russia consisted of: $:^{24}$

- machines and equipment, vehicles, instruments and devices: $32.1 \%-31.6 \%$

- mineral products: $26.3 \%-26.0 \%$

- metals and metal articles: $14.0 \%-14.5 \%$

- textiles, textile articles and shoes: $11.8 \%-12 \%$

- products of the chemical industry and related industrial branches: $8.7 \%-8.8 \%$

In total these categories of goods made up $97.6 \%$ of the total import volume from Kazakhstan to Russia in $2012 .{ }^{25}$

The single most important area of economic co-operation is not surprisingly the fuel and energy sector. Related to this co-operation in the following areas are also receiving official support:

- Electric-power industry

- Nuclear power industry, through joint uranium mining in Kazakhstan

- Oil and gas industry, especially the export of Kazakh oil through Russian territory

- Purchasing and marketing of Kazakh natural gas for supplies to other countries' markets

- Implementation of joint projects on hydrocarbon resources development in North Caspian Sea 
The issue of Kazakh oil transit is based on the long-term intergovernmental Agreement of June 7, 2002. Approximately $15.5 \mathrm{mln}$. tons of oil per year is transported through the Atyrau-Samara crude oil pipeline, whilst up to $5.5 \mathrm{mln}$. tons of oil a year being transported through the Makhachkala-TikhoretskNovorossiysk pipeline system. ${ }^{26}$

The transit of Kazakh oil through Russian territory has been carried out within the framework of the Caspian Pipeline Consortium (CPC). The governments of Russia and Kazakhstan own 50\% of $\mathrm{CPC}$, with the remaining $50 \%$ belonging to the crude producers that sponsored the commission of the project's first phase.

As for the gas industry cooperation takes place within the framework of the long-term intergovernmental Agreement of November 28, 2001. Since 2002 the delivery of crude gas from the Karachaganack gas deposit has been transported to the Orenburg Natural Gas processing plant by CJSC "KazRosGAz" - a joint venture between Gazprom and the Kazakh KazMunaiGaz. ${ }^{27}$

Since 2002 the project on cooperation in integrated uranium exploitation has been carried out at Kazakhstani uranium deposits. The Joint Declaration on Cooperation in the Peaceful Use of Nuclear Energy, signed by both Presidents in January, 2006, instructed the parties to devise a schedule for integrating nuclear-powered enterprises of both countries. A complex program for cooperation in the peaceful use of nuclear energy is being carried on the basis of this declaration. ${ }^{28}$

Furthermore, based on the October 3, 2006 Uralsk arrangement between both Presidents concerning the involvement of Kazakhstan in the Russian initiative on organizing the International Center for Uranium recovery (ICUR) on Russian territory, a corresponding Agreement was signed on May $10,2007 .^{29}$

\section{Border Trade}

Kazakhstan has trade and economic relations with 76 of the 89 constituent territories of the Russian Federation. ${ }^{30}$ Not surprisingly it is the constituent territories immediately bordering Kazakhstan which are characterized by increasingly active cooperation with their large neighbour. Promotion of transborder economic schemes can be witnessed by the supply of Kazakh coal from Ekybastuz to the power stations of the Urals and Siberia in exchange for supplies of electricity to Kazakhstan as well as the supplies of Kazakh mineral raw materials to ore mining and smelting plants in the South Ural district in exchange for their finished products. Furthermore, another good example to illustrate trans-border economic relations is the Kazakh supply of oil and liquid gas to processing plants in Samara, Orenburg Oblast and Bashkiria in exchange for supplies of oil products and natural gas. It is estimated that transregional and trans-border trade constitutes about $70 \%$ of the bilateral trade turnover. ${ }^{31}$

According to the Russian Embassy in Astana several major Russian companies have made large investments in Kazakhstan. The have been identified as the following: ${ }^{32}$

- Lukoil - 5 billion USD

- Gazprom - 1 billion USD

- Inter RAO UES of Russia - 0,2 billion USD

- Rusal - 0,4 billion USD

There are approximately 400 businesses involving Russian capital which operate in Kazakhstan. Playing a prominent role in terms of actively investing in Kazakhstan are companies such as the state corporation Rosatom, Rosneft, VTB Bank, Vneshekonombank (Russian Foreign Trade Bank), Mechel and Severstal. ${ }^{33}$ The total Russian investments in Kazakhstan have surpassed 7 billion USD. ${ }^{34}$

The state of trading relations is not, however, without its own problems. The development of Russian-Kazakh trade and economic relations faces a number of hurdles. The absence of reliable 
schemes for mutual settlements or for resolution of economic disputes is a major hindrance. Furthermore, transportation rates remain quite high. The legal and regulatory framework for establishing, and operating joint ventures and financial industrial groups needs reform.

\section{Space and Military Relations}

Co-operation has been carried out in the sphere of space exploration. Russia holds a lease on the Baikonur space-launch complex, located in Kazakhstan, which in January 2004 was extended until 2050. The Kazakh space missile system "Baiterek" is being constructed at the "Baikonur" space-launch complex on the basis of bilateral intergovernmental agreements signed in 2004 and 2005.

Russia and Kazakhstan also cooperate in the military and military-technical spheres. Russia provides supplies of Russian-manufactured weapons to Kazakhstan, as well as assistance in maintenance and upgrade of Kazakh military hardware. Russia has a lease on 4 military testing grounds located in Kazakhstan. Kazakh military personnel also receive training in Russian military training schools.

Co-operation between Russia and Kazakhstan is effective along the lines of CIS and other integration units - CSTO, EurAsES, SCO and CICMA. Since 2010 Russia, Kazakhstan and Belarus have been a part of the Customs Union. A Common Free Market Zone has been in effect since January 1, 2012, which provides an additional boost to more extensive integration processes within the former Soviet Union.

\section{Developments ${ }^{35}$}

The meeting between the respective Ministers of Foreign Affairs was held on January 25, 2013.

On February 8, 2013 the meeting between the two Presidents was held within the context of Nazarbayev's working visit to Moscow.

On May 29, 2013 the meeting between Presidents Putin and Nazarbayev, took place on the sidelines of the highest-level session of Supreme Eurasian Economic Council in Astana.

On May, 312013 talks between the Chairman of the Government of the Russian Federation and the Kazakh Prime took place within the framework of the Council of Heads of CIS States.

On July 7, 2013 the meeting of Presidents Putin and Nazarbayev, was held as part of the Russian President's working visit to Kazakhstan.

On April 10-12, 2013 talks were held between the Chairman of the Federal Assembly State Duma of the Russian Federation and the Chairman of Mazhilis of the Parliament of Republic of Kazakhstan, on "the side-lines" of PA CSTO, IPA CIS and IPA EurAsES.

On the 17th of June 2013 at the time of the official visit of the Chairman of Mazhilis of the Parliament of Republic of Kazakhstan, to Moscow he met with the Chairperson of Federation Council of Federal Assembly of the Russian Federation, and the Chairman of the Federal Assembly State Duma.

\section{China}

The Kazakhs share ancient historical ties to the Chinese, are geographically close and possess common interests in the spheres of security as well as political and economic cooperation. 
After Kazakh independence both countries demonstrated mutual interest in building stable and good-neighbourly relations and diplomatic relations were established early on in January $1992 .{ }^{36}$ It was the official visit by Kazakh President Nazarbayev to China in October 1993 which initiated regular meetings between the two countries at the head of state level. ${ }^{37}$ The Joint Declaration on the Foundations of Friendly Relations between the Republic of Kazakhstan and the People's Republic of China signed during this visit is one of the first agreements that defined the principles of interaction between the two countries. $^{38}$

According to this both sides immediately started to take steps to solve the problems inherited from the Soviet era. During the following years a particularly sensitive item affecting bilateral relations regarded the delimitation of the border. Several agreements were signed (in Shanghai in 1996, Moscow in 1997 and Almaty in 1998) within the Shanghai-Five organisation, with the result being that border problems were mostly solved and the delimitation and demarcation of all sectors of the Kazakh-Chinese border completed. ${ }^{39}$ In this instance Kazakhstan was one of the first in Central Asia to solve this sensitive topic in bilateral relations.

\section{Energy}

Given Chinese demand for energy, this issue was addressed throughout the 1900s. Cooperation in the oil and gas sector developed rapidly between the two countries with Chinese companies' actively becoming involved in the Kazakh oil and gas sector starting with China National Petroleum Corporation's (CNPC) purchase of a 60\% stake in Kazakhstan's Aktobemunaigas oil and gas company in 1997.40

In 2003, under the auspices of bilateral intergovernmental agreements in the oil and gas sector signed in 1997, companies in the two countries started to implementation a major project to build an oil pipeline from Kazakhstan to China. The first phase of the Atyrau-Kenkiyak oil pipeline was completed, the Atasu-Alashankou oil pipeline completed and commissioned in 2005, beginning to ship 6 million of oil to China in 2008. ${ }^{41}$ With the completion of the Kenkiyak-Kumkol and Kumkol-Atasu pipelines linking the earlier built Atyrau-Kenkiyak and Atasu-Alashankou pipelines, all Kazakh pipelines are unified as a single system and integrated into China's oil pipeline networks. ${ }^{42}$

The project which was carried out by the Kazakh KazMunaiGas national oil and gas company and the CNPC at the end of 2009 made the oil pipeline an important tool in diversifying routes to transport energy resources to global markets. ${ }^{43}$

As Kazakh-Chinese economic cooperation expands, with steady growth in trade and freight shipment, the importance of transport links has been growing constantly. Kazakhstan and China have huge, untapped opportunities to cooperate in the transit transport sphere.

Kazakhstan has been most active and forthright in the energy sector, making decisions concerning which direction to export. As China is increasing its energy imports, Kazakhstan has sought to meet as much of this demand as possible. Simply put in order to do this there has to be more supply. That become available near the end of 2013 with ExxonMobil and Royal Dutch Shell and others starting production in the Kashagan oilfield, one of the largest in the world. ${ }^{44}$

Having the resources, Kazakhstan embarked on four strategies to meet its self-defined goal of exporting greater amounts of energy to China. The first concerns expanding already established pipelines. A good example of this effort was identified by Kairkeldy Kabyldin, the director general of KazTransOil, who stated that the capacity of the Kazakhstan-China oil pipeline is set to almost double by next year through an extension that is predicted to cost approximately $\$ 667$ million. ${ }^{45}$

The second strategy is to start building new pipelines. Kazakhstan already exports gas through the Central Asia-China Gas Pipeline but aims to add an extension to it by 2015, which would supply natural gas from the Karachaganak, Tengiz and Kashagan gas fields. ${ }^{46}$ Given the fact that Astana in effect is a rival to Moscow in terms of pipelines to China, it has pursued its multi-vector foreign policy 
of careful balancing in the energy field. Russia has not been forgotten, through a projected $\$ 1.6$ billion Kartaly-Astana gas pipeline (Kartaly is located in Russia, bordering northern Kazakhstan) envisioned to extend as far as Karaganda and Petropavlovsk. ${ }^{47}$ This would supply gas to the Kazakh capital and construct gas supply networks in northern and central Kazakhstan from the Karachaganak field in the country's west, via Russia.

The third strategy employed by Astana concerns the Kazakhstan Caspian Transport System: to ship oil by tankers from the ports of Aktau and Kuryk to Baku, where they will be pumped into the Baku-Supsa and Baku-Tbilisi-Ceyhan pipelines. ${ }^{48}$ Additional pipelines from the newly discovered oilfields of Kashagan will be built to link it to Aktau. Therefore, the transfer of oil will not be restricted to overland pipelines.

The fourth strategy was again to build a pipeline -- but under the sea -- so as to directly connect to the Baku-Tbilisi-Ceyhan pipeline. While this underwater pipeline is technically feasible, the project has been put on hold due to firm objections by both Russia and Iran. Therefore, the abovementioned four measures clearly demonstrate that the Kazakhs have been quite committed to trying to garner a larger slice of the energy cake that China is desperate to consume.

Interestingly, while China certainly has a huge appetite to devour energy, it is also prepared to pay for its delivery. The China Development Bank (CDB) has played an exemplary role in financing energy infrastructural projects and ought to be labeled the "engine of Eurasian energy integration." 49 It has provided loans so that the Kazakhstan-China oil and the Trans-Asia gas pipelines could be constructed so that Central Asia looked more to the east when considering exporting energy. Amazingly, its total foreign currency lending grew more than twelvefold in six years (2005-2011). ${ }^{50}$ Overall trade with China rose to $\$ 24$ billion in 2012 , with the volume projected to reach $\$ 40$ billion by $2015 .{ }^{51}$

Apart from energy relations bringing the two countries closer there is also the human dimension where overlapping ethnic groups exist. Upto 200,000 Uyghurs live in eastern Kazakhstan with an additional million ethnic Kazakhs living in China. ${ }^{52}$ The Chinese government has periodically expressed concerns with regard to ethnic Muslim separatism in the Xinjiang Uyghur Autonomous Region, which encompasses about one-sixth of the land area of China. This is one leg of what the Chinese refer to as the three evils of terrorism, extremism and separatism. ${ }^{53}$

\section{USA}

The US was one of many countries to quickly recognise the newly independent Kazakhstan and establish diplomatic relations. Security has been at the forefront of the Kazakh-U.S. relationship. Cooperation in security, especially in nuclear non-proliferation, has been valued by both countries.

A very important topic at the time that affected the development of bilateral relations concerned Kazakhstan voluntarily giving up nuclear weapons. Kazakhstan showed leadership when it renounced its nuclear weapons in 1993 and closed the Semipalatinsk Test Site. ${ }^{54}$ This step confirmed Kazakhstan's adherence to peaceful development and significantly increased the level of mutual trust between the two countries.

The United States assisted Kazakhstan in the removal of nuclear warheads, weapons-grade materials, and their supporting infrastructure. In 1994, Kazakhstan transferred more than a half-ton of weapons-grade uranium to the United States. In 1995 Kazakhstan removed its last nuclear warheads and, with U.S. assistance, completed the sealing of 181 nuclear test tunnels at the STS in May $2000 .{ }^{55}$

In the following decade, the United States and Kazakhstan worked together to seal 40 more nuclear test tunnels at the STS. Kazakhstan signed the Conventional Armed Forces in Europe Treaty (1992), the START Treaty (1992), the nuclear Non-Proliferation Treaty (1993), the Chemical Weapons Convention, and the Comprehensive Test Ban Treaty (2001). ${ }^{56}$ 
Under the Cooperative Threat Reduction program, the United States spent \$240 million to assist Kazakhstan in eliminating weapons of mass destruction and weapons of mass destruction-related infrastructure ${ }^{57}$ Kazakhstan's military participates in the U.S.'s International Military Education and Training program and Foreign Military Financing. Therefore, U.S.-Kazakh cooperation in security and nuclear non-proliferation has remained a cornerstone of the relationship which has been evidenced by Kazakhstan's participation in the Nuclear Security Summits of 2010 and 2012.58

\section{Economic Relations}

Kazakhstan is the United States' 76th largest goods trading partner with $\$ 2.5$ billion in total (two way) goods trade for the year 2013. ${ }^{59}$ Goods imported from the U.S. totaled $\$ 1.1$ billion; whereas Goods exported totaled $\$ 1.4$ billion. Therefore, the U.S. goods trade deficit with Kazakhstan came to \$295 million in 2013 which highlighted a 56.8\% decrease (\$388 million) over 2012. ${ }^{60}$

In terms of exports, Kazakhstan was the United States' 74th largest goods export market in 2013. U.S. non-agricultural goods exports to Kazakhstan in 2012 were $\$ 882$ million, up 7\% (\$57 million) from a year ago. U.S. goods exports to Kazakhstan in 2013 were \$1.1 billion, up 24.2\% (\$213 million) from $2011 .{ }^{61}$

The top export categories in 2013 were: ${ }^{62}$

- Machinery - $\$ 333$ million

- Aircraft - \$204 million

- Electrical Machinery - \$127 million

- Vehicles - \$71 million

- Railway (locomotive parts) - \$70 million

Concerning imports, Kazakhstan was the United States' 70th largest supplier of goods imports in 2013. U.S. goods imports from Kazakhstan totaled \$1.4 billion in 2013, a 11.2\% decrease ( $\$ 175$ million) from $2012 .{ }^{63}$

The top import categories in 2013 were: ${ }^{64}$

- Mineral Fuels, Oils - $\$ 1.0$ billion

- Iron and Steel - \$123 million

- Inorganic Chemicals (enriched uranium) - \$108 million

- Other Base Metals (tantalum) - \$65 million

- Ores, Slag, Ash (uranium ores) - $\$ 49$ million

U.S. foreign direct investment (FDI) in (stock) was \$11.4 billion in 2012 which highlighted a decline of just over $3 \%$ compared to $2011 .^{65}$ These companies are concentrated in the energy sector, business services, telecommunications, and electrical energy sectors.

\section{Military Relations}

Vol. 13, No.4, Winter 2014 
In 2003, the two countries signed the first of a five-year plan of military cooperation. It covered countering international terrorism, developing peacekeeping forces, strengthening Kazakhstan's air defence forces, developing military infrastructure in the Caspian Sea and the Navy. The signing of the second five-year plan of military cooperation was an indicator of the expansion of military and political cooperation which aimed at realising national plans for the transformation of Kazakhstan's armed forces, the improvement of the country's peacekeeping potential and the development of the national | 80 system of military education and training, as well as the supplies of modern samples of military and technical equipment and vehicles.

Kazakhstan has also pursued cooperation with the United States within international organizations that they are both members of. These have included the United Nations, Organization for Security and Cooperation in Europe (OSCE), and NATO's North Atlantic Cooperation Council. Kazakhstan has been an active participant in NATO's Partnership for Peace program.

\section{Concluding Remarks}

Kazakhstan the ninth-largest country in the world is located between an ex-superpower and an emerging superpower. Whilst it has impressive natural resources the power and influence that possession of these brings, pales into insignificance compared to that of Russia and China. Kazakhstan has attempted to find the best path to both ensure survival and prosperity.

In its search for a solution to accommodate its two powerful neighbours as well as constituting a viable modern democratic state, a multi-vector foreign policy approach has been seen as the answer. Such a policy has permitted Astana to keep its historic good relations with the Russians, attract the United States in terms of investing in its economy, primarily the energy sector as well as taking up the opportunity to feed the increasing thirst for energy that stems from China's impressive economic growth.

The Kazakh Foreign Minister Erlan Idrissov declared in 2014 that "Recent foreign policy developments, including top-level meetings and visits, have once again demonstrated the critical importance of Kazakhstan's multi-vector foreign policy. Remaining true to the fundamental principles and values of this well-established doctrine is the only viable option for a country such as ours." ${ }^{.66}$ In March 2014, President Nazarbayev stated that "The foreign policy of Kazakhstan is balanced and multivector, and the....policy of Kazakhstan has been proofed to be on the right track by the practice"

The adoption of a multi-vector foreign policy has ensured the territorial integrity of Kazakhstan and provided itself with room for maneuverability in the international community. Looking at the situation the Kazakhs found themselves in 1991 at the onset of independence; one can certainly affirm that the choice of a multi-vector foreign policy has paid dividends.

\section{Notes}

\footnotetext{
${ }^{1}$ H. J. Mackinder., The Geographical Pivot of History The Geographical Journal, Vol. 23, No. 4. (1904),

2 "The World Factbook," accessed July 23, 2014, https://www.cia.gov/library/publications/the-worldfactbook/fields/2096.html.

${ }^{3}$ Ipek, P., The role of oil and gas in Kazakhstan's foreign policy: Looking east or west? Europe-Asia Studies 59 (7), 1179-1199

${ }^{4}$ Ipek, P., The role of oil and gas in Kazakhstan's foreign policy: Looking east or west? Europe-Asia Studies 59 (7), p. 1179-1180.

${ }^{5}$ Didar Kassymova, Zhanat Kundakbayeva, Ustina Markus, Historical Dictionary of Kazakhstan, Scarecrow Press, Lanham, Maryland, 2012.

${ }^{6}$ Fawn, Rick., Ideology and National Identity in Post-communist Foreign Policies, Psychology Press, Frank Cass, London, 2003.

7 "Multi - Vector Policy of the Republic of Kazakhstan. Part $1 \cdot$ Research Articles and Publications · E-Library ·

'Kazakhstan History’ Portal,’ accessed July 23, 2014, http://e-history.kz/en/books/library/view/1006.
} 
8 "The Transatlantic Vector of the Republic of Kazakhstan's Foreign Policy Strategy: Its State of Affairs, Problems and Prospects | EP TODAY," accessed July 23, 2014, http://eptoday.com/the-transatlantic-vector-of-the-republicof-kazakhstans-foreign-policy-strategy-its-state-of-affairs-problems-and-prospects/.

${ }^{9}$ Назарбаев Н.А. Укреплять международные позиции Казахстана // www.president.kz

${ }^{10}$ Ipek, P., The role of oil and gas in Kazakhstan's foreign policy: Looking east or west? Europe-Asia Studies 59 (7), 1179-1199

${ }^{11}$ Назарбаев Н.А. Укреплять международные позиции Казахстана // www.president.kz

12 "Kazakhstan $\square$ s Foreign Policy in a Time of Turmoil | EurasiaNet.org," accessed July 23, 2014, http://www.eurasianet.org/departments/insight/articles/eav042705.shtml.

13 "The Transatlantic Vector of the Republic of Kazakhstan's Foreign Policy Strategy: Its State of Affairs, Problems and Prospects | EP TODAY.'

14 "22 Years of Balanced Foreign Policy Yield Success, Lay Ground for Future» The Astana Times,” accessed July 23, 2014, http://www.astanatimes.com/2013/09/22-years-of-balanced-foreign-policy-yield-success-layground-for-future/.

${ }^{15}$ The foreign policy concenpt declares the "Basic principles and General Approaches of Foreign Policy of The Republic of Kazakhstan. Kazakhstan's foreign policy is based on the principles of multi-vector, balance, pragmatism, mutual benefit, and solid defense of its national interests. Kazakhstan stands for equality of all states, consideration of mutual interests and non-interference in the internal affairs of each other, as well as for peace and collective resolutions of international problems and conflicts on the basis of the UN Charter and the rule of international law." http://www.kazembassy.hr/c/1056/l/EN/Foreign-Policy-Concept-for-2014---2020-Republicof-Kazakhstan---The-Embassy-of-the-Republic-of-Kazakhstan-in-the-Republic-of-Croatia.wshtml

${ }^{16}$ Igor S. Zonn, M. Glantz, Aleksey N. Kosarev, Andrey G. Kostianoy., The Aral Sea Encyclopedia, Springer Science \& Business Media, Heidelberg, 2009.

17 "Russia-Kazakhstan | Russia-Kazakhstan Relations | The Embassy of the Russian Federation to the Republic of Kazakhstan,” accessed July 23, 2014, http://www.rfembassy.kz/eng/lm/dvustoronnie_otnosheniya/rossiyakazakhstan/.

18 ibid

19 ibid

${ }^{20}$ ibid

21 ibid

22 "Economic Cooperation | Russia-Kazakhstan Relations | The Embassy of the Russian Federation to the Republic of Kazakhstan,” accessed July 23, 2014, http://www.rfembassy.kz/eng/lm/dvustoronnie_otnosheniya/torgovoekonomicheskie_svyazi/.

23 ibid

24 ibid

25 ibid

26 ibid

27 ibid

28 ibid

29 ibid

30 ibid

31 ibid

32 ibid

33 ibid

${ }^{34}$ ibid

35 "Russia-Kazakhstan | Russia-Kazakhstan Relations | The Embassy of the Russian Federation to the Republic of Kazakhstan."

${ }^{36}$ Karrar, H., The New Silk Road Diplomacy: China's Central Asian Foreign Policy Since the Cold War, UBC Press, Vancouver, Canada, 2010.

${ }^{37}$ Tan, Chung., Rise of the Asian Giants: The Dragon-elephant Tango, Anthem Press, New Delhi, India, 2008.

${ }^{38}$ K. Santhanam, B. K. Sultanov., India-Kazakhstan relations: enhancing the partnership, University of Michigan, Ann Arbor, 2006

${ }^{39}$ Didar Kassymova, Zhanat Kundakbayeva, Ustina Markus, Historical Dictionary of Kazakhstan, Scarecrow Press, Lanham, Maryland, 2012.

$40 \quad$ "Kazakhstan," accessed July 23, http://www.hqcec.com/en/cnpcworldwide/kazakhstan/Kazakhstan.htm?COLLCC=1142988686\&COLLCC=742 559384\&.

${ }^{41}$ Carrie Liu Currier, Manochehr Dorraj., China's Energy Relations with the Developing World, Continiuum Books, New York, 2011 
${ }^{42}$ Robert E. Bedeski, Niklas Swanström., Eurasia's Ascent in Energy and Geopolitics: Rivalry Or Partnership for China, Russia and Central Asia?, Routledge, New York, 2012.

${ }^{43}$ ibid

44 "Kashagan Oil Field Starts Production - Oil \& Gas Journal," accessed July 23, 2014, http://www.ogj.com/articles/2013/09/kashagan-oil-field-starts-production.html.

| 8245 Süreyya Yiğit, "ORSAM :: Foreign Policy Analysis," accessed September 16, 2013, http://www.orsam.org.tr/en/showArticle.aspx?ID=1621.

46 ibid

47 ibid

48 ibid

${ }^{49}$ ibid

${ }^{50}$ ibid

51 "Kazakhstan Aims for Larger Share of China-Europe Transit Trade | Global Risk Insights," accessed July 23, 2014, http://globalriskinsights.com/2013/12/12/kazakhstan-aims-for-larger-share-of-china-europe-transit-trade/.

${ }^{52}$ Khanam, R., Encyclopaedic ethnography of Middle-East and Central Asia, Volume 3, Global Vision Publishing House, University of Michigan, Ann Arbor, 2005.

${ }^{53}$ Lanteigne, Marc., Chinese Foreign Policy: An Introduction, 2nd edition: An Introduction, Rotledge, New York, 2013.

54 “A Successful Strategic Partnership," accessed July 23, 2014, http://transatlantic-magazine.com/a-successfulstrategic-partnership-for-transatlantic-magazine/.

55 "Contribution to International Security | Embassy of the Republic of Kazakhstan," accessed July 23, 2014, http://www.kazakhembus.com/page/contribution-to-international-security.

${ }^{56}$ McTernan, Benedict., Political Risk Yearbook - 2009: Central and South Asia, PRS Group Incorporated,Cornell University, New York, 2009.

${ }^{57}$ International Business Publications., Kazakhstan Business Law Handbook: Strategic Information and Laws International Business Publications, Wasington D.C. USA, 2012

58 "Nuclear Security Summit at a Glance | Arms Control Association," accessed July 23, 2014, http://www.armscontrol.org/factsheets/NuclearSecuritySummit.

59 "Kazakhstan | Office of the United States Trade Representative," accessed July 23, 2014, http://www.ustr.gov/countries-regions/south-central-asia/kazakhstan.

${ }^{60}$ ibid

${ }^{61}$ ibid

62 ibid

63 ibid

${ }^{64}$ ibid

${ }^{65}$ ibid

66 "Ethnic Harmony and Multi-Vector Foreign Policy Key to Kazakhstan's Stability, Development » The Astana Times," accessed July 23, 2014, http://www.astanatimes.com/2014/04/ethnic-harmony-multu-vector-foreignpolicy-key-kazakhstans-stability-development/.

67 ibid 